\title{
CUSTOMER SATISFACTION ANALYSIS FOR ASSEMBLY SERVICES
}

\author{
Karolina CZERWIŃSKA ${ }^{1}$, Andrzej PACANA ${ }^{2 *}$ \\ ${ }^{1}$ Politechnika Rzeszowska im. I. Łukasiewicza, Rzeszów; k.czerwinska@prz.edu.pl, \\ ORCID: 0000-0003-2150-0963 \\ ${ }^{2}$ Politechnika Rzeszowska im. I. Łukasiewicza, Rzeszów; app@ prz.edu.pl, ORCID: 0000-0003-1121-6352 \\ * Correspondence author
}

Purpose: The aim of the study was to analyze and determine the level of satisfaction of individual customers in the field of transport and installation of wooden doors.

Design/methodology/approach: The assessment was carried out using the Servqual method within the five dimensions of providing a comprehensive service in terms of materiality, reliability, responsiveness to customer expectations, expertise and empathy. The survey was conducted on the basis of questionnaires, interviews with customers who used the service and observations.

Findings: On the basis of the research, it was found that the quality level of provided transport and assembly services is at a good level. In the opinion of customers, the assessment of the quality of services provided was over 4.3.

Research limitations/implications: In order to improve and enhance the level of customer satisfaction, remedial actions were proposed - additional training for transport and assembly groups.

Practical implications: Future research carried out in the analyzed company will allow to checking the impact of implemented countermeasures on the level of customer satisfaction. The methodology presented should be applied in companies that care about the quality of services offered. The limitations that may occur are related to the possible reluctance of customers to express an opinion on the service provided.

Originality/value: The research is a useful study indicating the possibility of implication of the Servqual method in service enterprises wanting to check the level of customer satisfaction.

Keywords: Servqual method, CSI indicator, quality management, comprehensive quality (TQ).

Category of the paper: research paper and case study.

\section{Introduction}

In the current highly competitive market, it is not enough to achieve and maintain a leading position simply by offering products or services without paying special attention to continuous improvement of their quality. Customers are increasingly considering not so much the product 
or service itself as the whole set of benefits offered by the manufacturer (Zięba, 2009). The quality of the service offered has a significant impact on the level of customer loyalty and relations with customers. Long-term customer relations are the basis of a company's profitability (Kachniewska, 2006). In order to build positive relationships with customers, it is necessary to constantly take care of meeting their needs and monitor their level of satisfaction (Hill, and Alexander, 2003).

There are many definitions and interpretations of the term customer satisfaction in the literature. Most authors agree that customer satisfaction is a phenomenon (emotional state, attitude, impression) occurring after the purchase and subsequent consumption, as a result of comparing expectations about the product with actual experiences of using it. (Stodulny, 2007; Morgan et. all 2005; Lou, and Homburg, 2007; Kotler et. al. 2000). The level of customer satisfaction reflects the level at which the product offered by a given company meets customer requirements (Hill, and Alexander, 2003).

There are two concepts of creating customer satisfaction, namely transactional and cumulative. Transactional satisfaction refers to a consumer's short-term experience of a product or service and is the result of a specific, usually one-off transaction (Stodulny, 2007). On the other hand, cumulative satisfaction is the result of the consumer's longer experience with a good or service. It refers to the overall assessment of the consumption of the product during the period considered. This satisfaction is a kind of capital and often influences the financial condition of a company (Witkowska, and Nieżurawski, 2007).

Many companies consider the highest value to be not so much customer satisfaction, but rather their superiority. This makes it necessary to distinguish satisfaction factors, which include (Rudawska, 2005): basic factors (indicating minimum requirements), performance factors (often also service quality features leading to satisfaction and arousal factors (factors causing increased customer satisfaction).

In order to verify and confirm that the product has reached the expected quality level, it should be evaluated. For this reason, many models have been developed. In literature, what are most common are: the emotional model (relating to cumulative satisfaction) (Nieżurawski et. al., 2007), Fair exchange theory (concerning transactional satisfaction) (Pawłowska et. al., 2010), the expected nonconformity model (relating to cumulative satisfaction) (Witkowska, and Nieżurawski, 2007), the confirmation/discounting model (Oliver, 1997), the Kano model (Urbanek, 2004), the PROSAT model (Nieżurawski, 2010), or the SERVQUAL quality of service model that determines the time when satisfaction is generated in relation to the quality assessment carried out from the customer's point of view. (Parasuraman et al., 1985; Rudawska, and Kiecko, 2000). 


\section{Research methodology}

The Servqual method was used to assess the level of quality of services provided in this study. This method was developed between 1983 and 1985 by A. Parasurman, V.A. Zeithamla and L. Berry (Kraszewski, 2001). Using the Servqual method, service providers are able to anticipate customer expectations and monitor the level of evaluation of the services provided to customers. This method is used to verify the evaluation of quality through the difference between the expectations of customers and their actual experiences during the service. Thanks to its application, it is possible to implement the concept of continuous improvement and to involve the entire company, including all employees, in this process and to build an efficient communication system. The authors of the Servqual method assumed that the quality of provided services is defined as the difference between the experience - the perception of the service recipient and his/her expectations towards specific services. Within the established assumptions, it is possible to examine service quality according to the guidelines of the TQM approach (Arash, and Nassibeh, 2011; Borkowski, and Wszendybyl, 2007; Karaszewski, 2005; Zeithaml, et al., 1990). A model of "the five gaps" on which the Servqual method is based is shown in Figure 1.

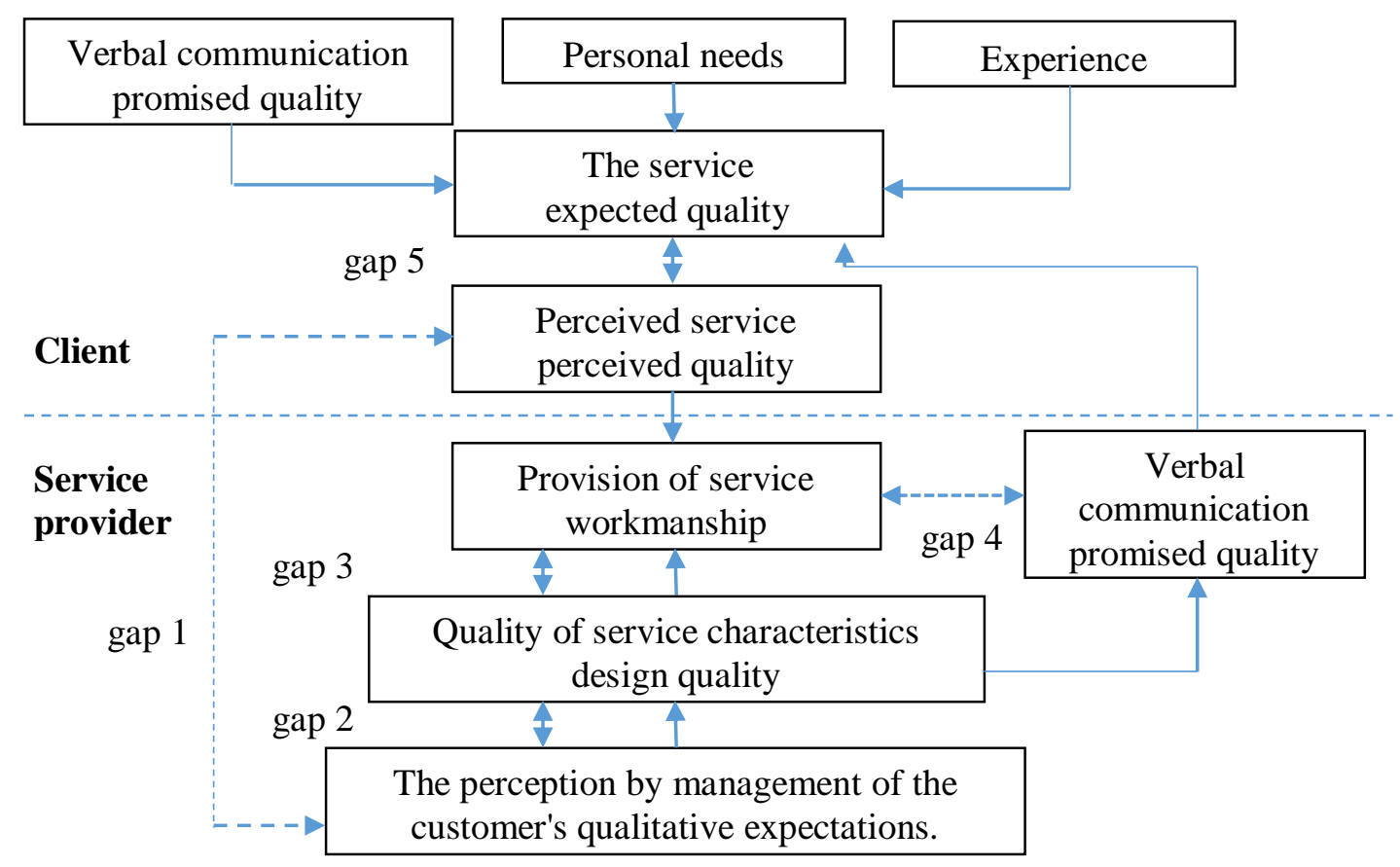

Figure 1. Servqual service quality model. Source: E. Krzemień, R. Wolniak, Zarządzanie jakością w sektorze usług finansowych. Wyższa Szkoła Bankowości i Finansów, Bielsko-Biała 2004; A. Parasurman, V. A. Zeithaml, L. L. Berry: A conceptual model of service quality and its implications for the future research. "Journal of marketing" 1985, Vol. 40. 
Servqual has five service quality vulnerabilities affecting the customer's dissatisfaction and, as a result, contributing to poor quality assessment (Karaszewski, 2001):

- The first gap is defined as the difference between the expectations of the service recipient and the perception of requirements by the management of the company.

- The second gap is the differences between the management's perception of service, recipients' expectations and the specification of service quality.

- The third gap concerns the difference between the specification of service quality and the quality of the provision of a specific service.

- The fourth gap relates to the difference between the quality of service provision and the information that the recipient has obtained about it.

- The fifth gap is the difference between the level of fulfilment of the service recipient's expectations and their perception of the service.

The high quality of the service to the satisfaction of the recipient is demonstrated by a situation where there are no gaps. The greater the discrepancy, the lower the score will be. As a result, only the introduction of the Total Quality (TQ) concept can lead to full customer satisfaction.

The basic research tool was a questionnaire, the results of which were enriched during interviews in the area of expectations and evaluation of the level of qualitative features, which were distinguished on the basis of the fifth gap model, expressing the difference between the level of fulfilment of expectations and the perception of service quality by the service recipient (Briggs et. al., 2010; Gounaris, 2005; Szkoda, 2013).

The questionnaire used in the study, in accordance with the recommendations contained in the literature (Karaszewski, 2001; Witkowska, 2007; Urbaniak, 2013; Wolniak, and Skotnicka, 2008), consisted of two parts:

- in the first part, the respondents communicate their expectations of the service. A sevenpoint Likert scale was applied to each question, allowing for grading the level of expectations of the service recipient in relation to services. In the applied scale, the value of 7 indicates that the recipient of the service agrees with a given feature, while 1 thinks that it is redundant.

- In the second part, the respondents provide their opinions on the perception of the level of service provided. This section of the questionnaire also includes a seven-point evaluation scale. The indication of the number 7 indicates that the customer is fully satisfied with the service after the service has been provided, and rating 1 means that the customer is not satisfied with the service.

Reliable collection and analysis of information concerning customers'; expectations will enable to adjust the production company's offer to the needs and expectations of customers, which in turn will contribute to the success of the business. 


\section{Purpose of the studies}

The aim of the work is to analyse and determine the level of satisfaction of individual customers in the area of transport and assembly of wooden doors carried out by three teams employed by Agmar company. The evaluation was carried out within the framework of five dimensions of providing a comprehensive service, i.e.: material dimension, reliability, response to customer expectations, professionalism and empathy. The analysed company has a team of employees, performing transport and assembly services in the province where the company's headquarters are located (team I). In addition, the company cooperates with two companies in the field of the execution of transport and assembly orders in nearby provinces (group II and group III).

On the basis of observations and conversations with customers who have used the transport and assembly service, it was assumed that there are differences between the expectations of service recipients and what they actually receive, resulting in differences (the so-called gaps) between the level of importance of the indicated attributes and the level of satisfaction with the service provided.

\section{Analysis}

The study used the Servqual method to determine the level of customer satisfaction with the service provided. Each of the distribution channels was examined separately by selecting the customers using the services of a given channel.

Clients were asked to express their opinion based on their experience gained while using the services of transport and assembly of the purchased goods. Consumer views were presented in three areas:

- as a distribution and assembly channel that service recipients would like to use in the future and ideas about the quality of services provided by this channel,

- the distribution and assembly channel currently used by the recipients of the service,

- the minimum level of service acceptable to the recipient.

The comparison of the obtained average assessments of the level of expectations and the current situation related to the provision of the service by particular distribution channels makes it possible to determine those areas where the disproportions are greatest. In order to determine which of the five analysed areas of the service provided requires as a first step the implementation of improvement measures, it is necessary to assess the size of the gap, the level in which, according to the customers, the current quality of provided services is in relation to the service quality tolerance zone and the importance of a given area for customers. A greater 
increase in customer satisfaction will be achieved by closing a larger gap and a smaller one by closing a smaller gap.

However, it should be borne in mind that closing a smaller gap, concerning an important issue for the customer, may contribute to greater satisfaction than addressing a larger gap, concerning a less important issue.

Team I is the distribution factor that consumers use most often when buying products offered by Agmar. The biggest differences between the expected and current values concerning the quality of transport and assembly services provided by the team were observed in the area of expertise and empathy. The highest expectations were reported by the respondents in the area of expertise (6.71). The smallest value of the gap between expected and current quality was recorded in the reliability area (1.28). Taking into account the tolerance zone, it can be seen that the current quality of provided transport and assembly services is within the tolerances specified by customers. However, the area where improvement measures should be implemented in the first place is the area of expertise, as the current quality of services provided is only 0.06 points within the tolerance. The material area also needs to be improved immediately, as there are not great differences between the current quality of service and the lower limit of the tolerance zone (Figure 2).

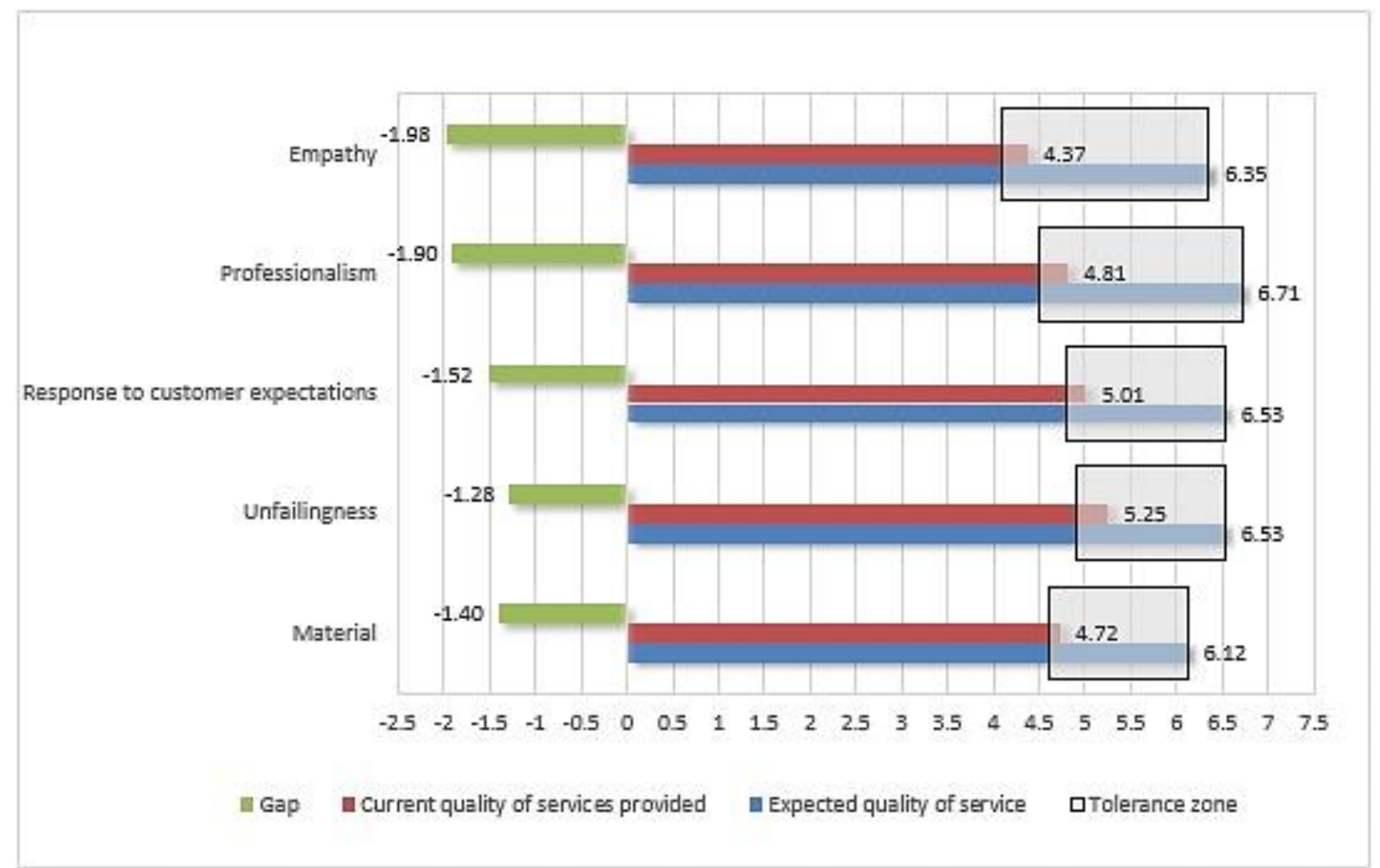

Figure 2. The gap between the current and expected quality of transport and assembly services for wooden doors provided by Team I. Source: own study.

The biggest difference between the actual quality of services provided by team II employees and the expected quality was identified in the area of reliability (1.83) and the smallest in empathy (0.69). Customers expect the highest quality of service within reliability, and the least attention is paid to empathy. When looking at the difference between the expected 
and current quality of service for the areas specified, it can be seen that, according to customers, significant differences exist in terms of expertise $(\mathrm{gap}=1.83)$ and reliability (gap $=1.70)$. With regard to the tolerance zones for individual areas, the results are a warning for the company, as three areas (material, reliability and expertise) are on the border with the tolerance zone. Therefore, it is in these areas that remedial action should be implemented first (Figure 3).

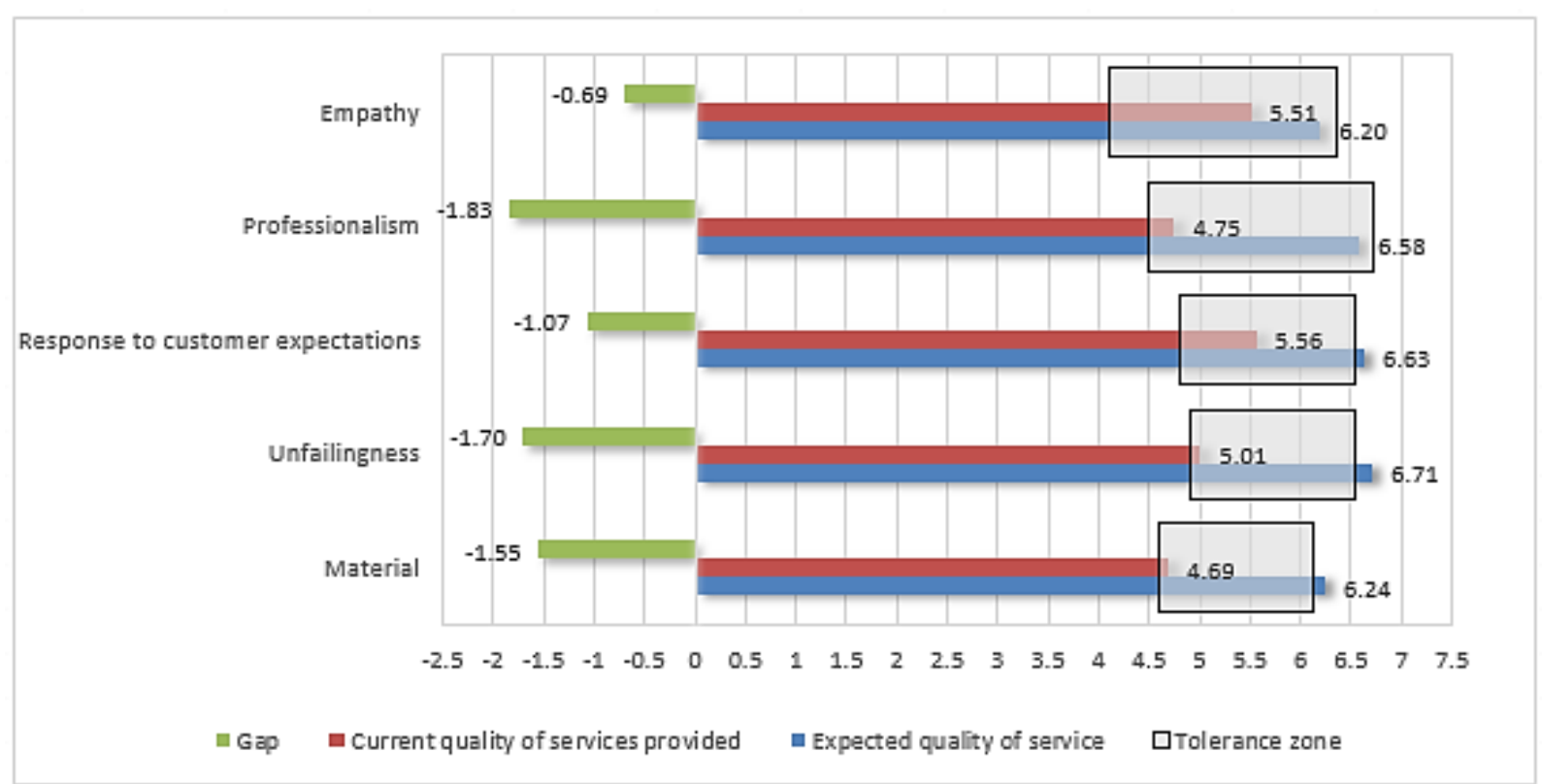

Figure 3. The gap between the current and expected quality of transport and assembly services for wooden doors provided by Team II. Source: own study.

In the distribution channel that makes up Team III (Figure 4), the largest gap was observed between the expected and current quality in the empathy area (1.85) and the lowest in the reliability area (1.02). The level of current quality was rated lowest in terms of empathy (4.44) and slightly higher in terms of expertise (4.82). Team III is characterized by a low level of empathy, which is not a problem for customers. Considering the issue of undertaking improvement actions, the assessment of Team III indicates that despite the highest score in the area of expertise among transport and assembly teams, such actions should also be implemented in this team, as the team's expertise is rated only 0.22 points above the minimum limit of the tolerance zone. 


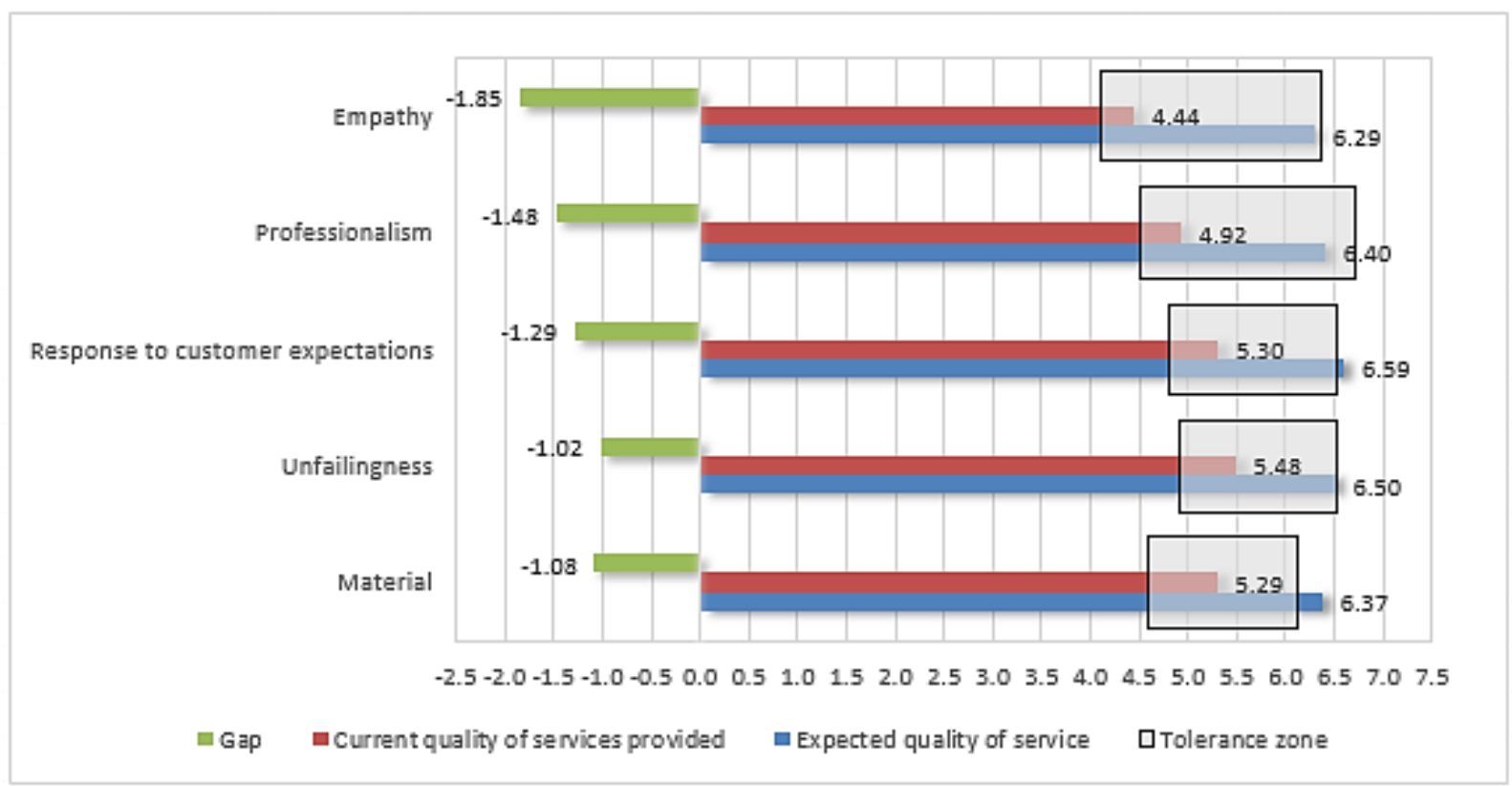

Figure 4. The gap between the current and expected quality of transport and assembly service of wooden doors provided by Team III. Source: own study.

In addition, customers gave the above areas weight (from 0 to 100 points). By taking into account the importance assessments made when assessing service attributes, weights were calculated that enabled the Customer Satisfaction Index (CSI) to be used in the analysis of the level of satisfaction with transport and assembly services. This indicator is one of the basic qualitative tools for measuring the effectiveness of marketing activities, and at the same time, it enables the measurement of customer satisfaction in relation to specific categories considered by customers to be of major importance (Wolniak, and Skotnicka-Zasadzień, 2008; Kozielski, 2004; Hll, 2013; Drapińska, 2013).

The CSI indicator is a weighted average of the buyer's satisfaction with the service attributes - the rating multiplied by the weighting assigned to each factor (Drapińska, 2013). The CSI can be expressed as a percentage to maximize the result and, thanks to the specified ranges, it can be interpreted correctly. The CSI assessment criteria are within the following ranges (Frąś, 2014):

- $0 \%-40 \%$ - very low - it shows extreme customer dissatisfaction,

- $40 \%-60 \%$ - low - indicates customer dissatisfaction,

- $60 \%-75 \%$ - on average - indicates some problems in customer satisfaction,

- $75 \%-90 \%$ - well - indicates few problems in customer satisfaction,

- $90 \%$ - $100 \%$ - very well - it proves customer satisfaction.

In order to calculate the Customer Satisfaction Index for the analysed distribution channels, a partial Customer Satisfaction Index (1) has been used for each area, which, when added together, enabled the CSI to be calculated (Table 1). 
partial $C S I=\frac{w_{n} \cdot c_{n}}{n}$

where:

$\mathrm{W}_{\mathrm{n}}$ - average weight (relevance) of the $\mathrm{nth}$ attribute,

$c_{n}$ - average score from individual areas,

$\mathrm{n}$-maximum score.

Table 1.

Level of customer satisfaction with distribution and assembly services

\begin{tabular}{|c|c|c|c|c|c|c|c|c|c|}
\hline \multirow[b]{2}{*}{$\begin{array}{c}\text { Service } \\
\text { dimension }\end{array}$} & \multicolumn{3}{|c|}{ Team I } & \multicolumn{3}{|c|}{ Team II } & \multicolumn{3}{|c|}{ Team III } \\
\hline & 总 & $\begin{array}{l}\vec{E} \\
\frac{200}{20} \\
3\end{array}$ & Ẽ & 总 & $\begin{array}{l}\vec{E} \\
\frac{000}{00} \\
3\end{array}$ & 馬 & 总是 & $\begin{array}{l}\vec{E} \\
\frac{000}{20} \\
3\end{array}$ & 昰 \\
\hline Material & 4.72 & 14 & 9.44 & 4.69 & 13 & 8.71 & 5.59 & 14 & 11.18 \\
\hline Unfailingness & 5.25 & 25 & 18.75 & 4.75 & 29 & 19.68 & 8.48 & 25 & 30.29 \\
\hline $\begin{array}{c}\text { Response to } \\
\text { customer } \\
\text { expectations }\end{array}$ & 5.01 & 19 & 13.60 & 5.56 & 19 & 15.09 & 5.30 & 24 & 18.17 \\
\hline Professionalism & 4.69 & 24 & 16.08 & 4.75 & 21 & 14.25 & 4.82 & 17 & 11.71 \\
\hline Empathy & 4.37 & 18 & 11.24 & 5.51 & 17 & 13.38 & 4.44 & 15 & 9.51 \\
\hline CSI & $\mathrm{x}$ & $\mathrm{x}$ & 69.11 & $\mathrm{x}$ & $\mathrm{x}$ & 71.11 & $\mathrm{x}$ & $\mathrm{x}$ & 80.86 \\
\hline
\end{tabular}

Source: own study.

It turned out that the overall level of customer satisfaction is $73.69 \%$. According to the criteria for evaluating the indicator, it can therefore be concluded that the result is only average. The company and the transport and assembly teams should make every effort to achieve the highest possible ratio. Measures should be implemented to reduce the largest gaps and corrective actions should be developed in the form of training in areas where there is a small difference between the current level of service quality and the lower limit of the tolerance zone. It was considered that actions targeted at these areas would be the best and quickest way to improve this indicator in a sustainable manner.

The improvement of the identified gaps in the area of reliability and professionalism should be achieved through additional training for the transport and assembly teams. However, it is not possible to close all the gaps quickly and inexpensively and to increase the level of quality of the services provided, all the more so because a significant gap has occurred for the material dimension and its closure is an investment in newer rolling stock and replacement of a significant part of tools, which is not easy. 


\section{Conclusion}

A high level of satisfaction of the service recipient is the desired final effect of services provided or activities undertaken by enterprises. However, in order to obtain it and then maintain it, it is necessary to offer what the consumer currently needs, at a price that meets his or her expectations, while taking care to ensure that the service is easily accessible and of appropriate quality.

Servqual method is an approach that examines the level of customer satisfaction in subsequent areas and thus enables the analysis of customer satisfaction in terms of characteristics relevant to consumer satisfaction and the service as a whole. This method is also an excellent tool for making decisions about the company's marketing strategy. Furthermore, it enables analysis of changes in preferences and, on this basis, allows the level of satisfaction to be assessed.

On the basis of the research carried out and the results obtained, it can be concluded that the quality level of transport and assembly services is at a good level. In the opinion of customers, the assessment of the quality of services provided was over 4.3 points and the identified gaps did not exceed 2 points.

The survey also showed that an overall customer satisfaction level (CSI index) of 73. 69\% is an average result - indicating some customer satisfaction problems. The company should endeavour to increase the CSI index to a higher level. First of all, the company should focus on bridging the gap in the area of "professionalism". The gap should be reduced due to its significant values in the three analysed groups and due to the high level of relevance of the professional aspect to clients. To do this, the proposed corrective measures - additional training for assembly groups - should be implemented. What is more, the company should continue to systematically carry out customer satisfaction surveys on its transport and assembly services.

The empirical studies presented confirmed the importance of the research problem addressed. The study fully justifies the advisability of the undertaken research aimed at determining the level of customer satisfaction with the quality of logistics services provided in the transport and assembly of wooden products.

\section{References}

1. Arash, S., Nassibeh, J. (2011). Estimation of Customer Dissatisfaction Based on Service Quality Gaps by Correlation and Regression Analysis in a Travel Agency. International Journal of Business and Management, 6, 3.

2. Borkowski, S., Wszendybył, E. (2007). Jakość i efektywność usług hotelarskich. Warszawa: PWN. 
3. Drapińska, A. (2013). Pomiar lojalności klientów - wybrane wskaźniki. Zeszyty Naukowe SGGW w Warszawie. Polityki Europejskie, Finanse i Marketing, 9(58).

4. Frąś, J. (2014). Wybrane instrumenty pomiaru jakości usług logistycznych. Zeszyty Naukowe Uniwersytetu Szczecińskiego, 803, Finanse, Rynki Finansowe, Ubezpieczenia. Wydawnictwo Naukowe Uniwersytetu Szczecińskiego.

5. Hall, H. (2013). Zastosowanie metody NPS i CSI w badaniach poziomu satysfakcji i lojalności studentów. Modern Management Review.

6. Hill, N., Alexander, J. (2003). Pomiar satysfakcji i lojalności klientów. Kraków: Oficyna Ekonomiczna.

7. Kachniewska, M. (2006). Modele jakości usług a specyfika produktu turystycznego. In: Turystyka w badaniach naukowych. Rzeszów: WSIiZ.

8. Karaszewski, R. (2005). Zarządzanie jakościa. Koncepcje, metody i narzędzia stosowane przez liderów światowego biznesu. Toruń: Dom Organizatora TNOiK.

9. Kotler, P., Armstrong, G., Saunders, J., Wong, V. (2000). Marketing. Podręcznik europejski. Warszawa: PWE.

10. Kozielski, R. (2004). Wskaźniki marketingowe. Kraków: Oficyna Ekonomiczna.

11. Kraszewski, R. (2001). TQM teoria i praktyka. Torun: TNOiK Dom Organizatora.

12. Krzemień, E., Wolniak, R. (2004). Zarzadzanie jakościa w sektorze usług finansowych. Bielsko-Biała: Wyższa Szkoła Bankowości i Finansów.

13. Lou, X., Homburg, C. (2007). Neglected Outcomes of Customer Satisfaction. Journal of Marketing, 71.

14. Morgan, N., Anderson, E., Mittal, V. (2005). Understanding Firms' Customer Satisfaction Information Usage. Journal of Marketing, 69.

15. Nieżurawski, L., Pawłowska, B., Witkowska, J. (2010). Satysfakcja klienta. Strategia, pomiar, zarządzanie. Toruń: UMK.

16. Oliver, T.A. (1997). Satisfaction: A Behavioral Perspective on the Consumer. Boston, MA: Irwin McGraw-Hill.

17. Parasuraman, A., Zeithaml, V.A., Berry, L.L. (1985). A conceptual model of service quality and its implications for future research. Journal of Marketing.

18. Pawłowska, B., Witkowska, J., Nieżurawski, L. (2010). Nowoczesne koncepcje strategii orientacji na klienta. Warszawa: PWN.

19. Rudawska, E. (2005). Lojalność klientów. Warszawa: PWE.

20. Rudawska, E., Kiecko, R. (2000). Servqual - metoda badania jakości usług i jej praktyczne zastosowanie. Marketing i Rynek.

21. Stodulny, P. (2007). Analiza satysfakcji i lojalności klientów bankowych. Warszawa: CeDeWu.

22. Szkoda, M. (2013). Realizacja procesów logistyki dystrybucji z zastosowaniem systemu SAP ERP. Logistyka, 5. 
23. Urbanek, G. (2004). Jakość, satysfakcja, lojalność rentowność-łańcuch przyczynowo skutkowy. Marketing i Rynek, 6.

24. Urbaniak, A. (2013). Zastosowanie metody Servqual do oceny jakości usług rekreacyjnych. Zeszyty Naukowe Uczelni Vistula, 32. Warszawa.

25. Witkowska, J. (2007). Metoda Servqual w badaniach satysfakcji klientów usług ubezpieczeniowych. Problemy Jakości, 39, 10.

26. Witkowska, J., Nieżurawski, L. (2007). Pojęcie satysfakcji klienta. Problemy Jakości. Wydawnictwo SIGMA-NOT.

27. Wolniak, R., Skotnicka, B. (2008). Metody i narzędzia zarządzania jakością. Gliwice: Wydawnictwo Politechniki Śląskiej.

28. Wolniak, R., Skotnicka-Zasadzień, B. (2008). Wybrane metody badania satysfakcji klienta i oceny dostawców w organizacjach. Gliwice: Wydawnictwo Politechniki Śląskiej.

29. Zeithaml, V.A., Parasuraman, A., Berry, L.L. (1990). Delivering Quality Service. New York: The Free Press.

30.Zięba, K. (2009). Poziom obstugi klienta jako źródło przewagi konkurencyjnej. In: I. Rudawska, M. Soboń (eds.), Przedsiębiorstwo i klient w gospodarce opartej na usługach. Warszawa: Difin. 